\title{
Effects of Seed Invigoration Treatments on Seed Germination, Seedling Vigour and Physio- biochemical Characteristics of Angelica glauca EDGEW -An Endangered Medicinal Herb
}

\author{
Anju Thakur* and Neha Sayal
}

Dept. of Basic Sciences, Dr. Yashwant Singh Parmar University of Horticulture and Forestry, Nauni, Solan, H.P. (173 230), India

\section{Corresponding Author}

Anju Thakur

e-mail: thakuranju2009@gmail.com

\author{
Article History \\ Article ID: 3 C0640 \\ Received in $26^{\text {th }}$ October, 2017 \\ Received in revised form $27^{\text {th }}$ April, 2018 \\ Accepted in final form $24^{\text {th }}$ May, 2018
}

\begin{abstract}
The present study was aimed to conserve Angelica glauca, a high altitude medicinal herb of North-Western Himalayas through innovative methodology to overcome dormancy, induction and synchronization of seed germination and vigour and also to understand underlying physio-biochemical changes. This species has become critically endangered on account of poor germination percentage, unsustainable and indiscriminate in-situ harvesting, so a prioritized herbal species for conservation. In nature Angelica glauca is generally propagated through seeds. Seeds of Angelica glauca show erratic, asynchronous and low germination due to embryonic immaturity and seed coat imposed dormancy which altogether decelerates the conservation strategy of this species. Seeds of Angelica glauca were collected from their natural populations at height of $1525 \mathrm{~m}$ amsl and tested for viability and germination. These seeds were further subjected to wide range of pre-sowing treatments. Study revealed that most of the tested treatments were found effective in improving germination and vigour as well as germination related indices. However, $\mathrm{GA}_{3} 100 \mathrm{ppm}$ for $72 \mathrm{hrs}$ induced highest germination percentage (41.11\%), followed by $\mathrm{KNO}_{3} 500$ ppm for $48 \mathrm{hrs}$ (35.55\%), PEG 6000 at -0.5 MPa for $12 \mathrm{hrs} \mathrm{(33.33 \% )} \mathrm{and} \mathrm{thiourea} 200$ ppm for 30 mins (31.11\%) as compared to control (22\%). It was coupled with higher mobilization efficiency, imbibition capacity, $\alpha$-amylase, protease and dehydrogenase activities , total soluble sugars and lower total phenols.
\end{abstract}

Keywords: Angelica glauca, dormancy, endangered, germination percentage, mobilization efficiency

\section{Introduction}

Angelica glauca commonly known as Chora is critically endangered high altitude medicinal herb of North-Western Himalayas belonging to family Umbelliferae (Apiaceae). Roots of Angelica glauca yield oil containing lactones and ses-quiterpenes and used as stimulant, carminative and diaphoretic. The plant roots contain $1.3 \%$ essential oil, angelic acid and angelicin resin (Blake, 2004). Extensive utilization of this species for their wide ranging medicinal applications causing unsustainable in-situ harvesting led this species to become critically endangered for the Himalayas (Badola and Pal, 2002). It occupies the topmost rank among prioritized medicinal plants of the Western Himalayas for conservation (Sastry and Chatterjee, 2000). In nature Angelica glauca is propagated through seeds and occasionally through root segments. The seed mediated propagation is unsatisfactory due to dormancy and poor germination percentage. Seeds of Angelica glauca of Uttaranchal population show at the most only $8 \%$ germination (Nautiyal et al., 2002). Butola and Badola, (2004) also reported that $A$. glauca reveal low and irregular patterns of seed germination. Seeds of some other species of family Apiaceae also show very low and delayed germination due to embryonic immaturity and seed coat imposed dormancy (Rouhi et al., 2012).These factors decelerate the conservation strategy of these species. There is little information on the germination ability and underlying physio-biochemical status of seeds of Angelica glauca (Nautiyal et al., 2002 ; Butola and Badola, 2004). Significance of presowing seed treatments to break dormancy and improve the germination ability of seeds is well established (Thakur, 2008; Bhardwaj et al., 2016; Thakur and Himangini 2015; Negi et al., 2017). Key Physiological phenomena like mobilization of stored reserves, imbibitions phenol content and other biochemical changes play a crucial role during seed germination(Yang et.al, 2016; Tejavathi et al., 2017; Zhao et al., 2018). Therefore, efforts were made in the present study to test the efficacy of different presowing treatments to remove dormancy, improve overall germination percentage and vigour and also to understand the underlying physiobiochemical changes for boosting conservation.

\section{Materials and Methods}

Seeds of Angelica glauca were collected from their natural populations in Rohru (1525 m amsl) Himachal Pradesh, during 
the last week of September, 2015. Thereafter, seeds were cleaned and air dried at room temperature and their viability was testedby tetrazolium chloride test which showed $54 \%$ viability. Seeds were surface sterilized with $0.1 \%$ mercuric chloride for 1 minute, thoroughly washed with distilled water thrice to remove the strains of mercuric chloride completely and subjected to wide range of seed invigoration treatments viz. Chilling at $5{ }^{\circ} \mathrm{C}$ for 4 weeks, GA 100 ppm for $48 \mathrm{hrs}, \mathrm{GA}_{3}$ 100 ppm for 72 hrs, GA 200 ppm for 48 hrs, GA 200 ppm for $72 \mathrm{hrs}, \mathrm{KNO}_{3} 250 \mathrm{ppm}$ for $72 \mathrm{hrs}, \mathrm{KNO}_{3} 500$ ppm for 48 hrs, Thiourea 100 ppm for 30 mins, Thiourea 200 ppm for 30 mins, PEG 6000 at $-0.5 \mathrm{MPa}$ for $12 \mathrm{hrs}$, PEG 6000 at $-0.5 \mathrm{MPa}$ for 24 hrsPEG 6000 at -1.1 MPa for $12 \mathrm{hrs}$ and PEG 6000 at -1.1 MPa for $24 \mathrm{hrs}$ along with one set of untreated seeds to serve as control. Thereafter, treated seeds in three replicates of 30 seeds each were allowed to germinate in petri dishes lined with Whatman No.1 filter paper, using top paper method in seed germinator at $25 \pm 2{ }^{\circ} \mathrm{C}$ and $80 \% \mathrm{RH}$ under $16 \mathrm{hrs}$ light and $8 \mathrm{hrs}$ dark periods. The experiment was conducted in CRD.

\subsection{Germination and vigour characteristics}

Germination percentage and other attributes were tested according to ISTA (1976). The formulae used are as follows:

$$
\begin{aligned}
& \text { Germination }(\%)=\text { No. of seeds germinated } \times 100 \\
& \text { Total no. of seeds kept } \\
& \text { for germination }
\end{aligned}
$$

Onset of germination (days): Seeds kept for germination were observed daily and the day when the first seed showed germination was considered as the time taken for onset of germination.

MGT (days) $=\sum($ nixdi) $/ N$

Where, ni is the number of germinated seeds on day $i$; $d$ is the incubation time (day); $\mathrm{N}$ is the total number of seeds germinated.

Germination speed: Daily count on normally germinated seeds was made upto $108^{\text {th }}$ from the day of sowing. The speed of germination was calculated by using the following formula, suggested by Maguire (1962).

Speed of germination $=\begin{array}{ccc}n_{1} & n_{2} & n_{x} \\ 1 & ----\end{array}$

Where, $\mathrm{n}_{1}, \mathrm{n}_{2}, \mathrm{n}_{\mathrm{x}}$ are the number of seeds germinated on day $1^{\text {st }}$ to $108^{\text {th }}$ day and $1,2,3----------x$ are the number of days

$$
\text { Germination percentage }
$$

Day of completion of germination

Seedling vigour indices-I and II were calculated as per the following formula :

Seedling vigour index-I =Germination $(\%) \times$ Seedling length $(\mathrm{cm})$ Seedling vigour index-II=Germination (\%)×Seedling dry weight (g)

\subsection{Physio-biochemical characteristics}

Imbibition capacity (\%): Pre-weighed seeds were immersed in the beaker containing distilled water. The seeds were allowed to imbibe water at room temperature i.e. $32{ }^{\circ} \mathrm{C} \pm 2$. Thereafter, these seeds were removed, wiped with absorbent paper and weighed, upto $9 \mathrm{hrs}$ after every $3 \mathrm{hr}$ interval. This method is modified method described by Kandari et al. (2008).

Mobilization efficiency (\%): Seed samples after initial recording of dry weight were allowed to germinate in Petri dishes in seed germinator at optimum temperature $\left(25^{\circ} \mathrm{C} \pm 2^{\circ} \mathrm{C}\right)$. Thereafter, seed remnants were dried separately at room temperature for 24 hrs (Srivastava and Sareen, 1974). Mobilization efficiency was calculated by following formula:

$$
\begin{gathered}
\begin{array}{c}
\text { Dry weight of original seed-Dry } \\
\text { weight of seed remnant }
\end{array} \\
\text { Mobilization efficiency }(\%)=\begin{array}{c}
\text { Dry weight of the } \\
\text { original seed }
\end{array}
\end{gathered}
$$

Total soluble sugars were determined as per the method of Dey (1990) using alcohol as extraction medium and total phenols content were estimated according to Singleton et al. (1999) using ethyl alcohol as extraction medium.

A-amylase activity was assayed by extracting the enzyme in Tris maleate - $\mathrm{NaOH}$ buffer and estimated according to Filner and Varner (1967). Protease activity was determined according to the method given by McDonald and Chen (1965) andtotal dehydrogenase activity was determined as per Bialecka and Kepczynski (2010).

\subsection{Statistical analysis}

The data generated during this study were appropriately computed, tabulated and analyzed by Completely Randomized Design (CRD). The level of significance was tested for different variables at $5 \%$.

\section{Results and Discussion}

\subsection{Germination and vigour characteristics}

Table 1 reveals that untreated (control) seeds showed $22.22 \%$ germination, onset of germination after 37.33 days and mean germination time (MGT) of 43.03 days, whereas seeds invigorated with $\mathrm{GA}_{3} 100 \mathrm{ppm}$ for $72 \mathrm{hrs}$ resulted in maximum germination percentage $(41.11 \%)$ alongwith earliest onset (15.33 days) and shortest mean germination time (20.64 days) and this was coupled with maximum speed of germination (0.624) and germination energy (1.548). Other effective treatments with regard to germination percentage were $\mathrm{KNO}_{3} 500$ ppm for $48 \mathrm{hrs}$ (35.55\%), PEG 6000 at -0.5 MPa for $12 \mathrm{hrs}$ (33.33\%) and thiourea 200 ppm for 30 mins (31.11\%). The maximum seedling dry weight $(0.011 \mathrm{~g})$ was registered by seeds subjected to chilling at $5^{\circ} \mathrm{C}$ for 4 weeks and PEG 6000 at $-0.5 \mathrm{MPa}$ for $24 \mathrm{hrs}$ both. Maximum seedling vigour indices $-I$ (181.35) and II (0.282) were obtained in seeds invigorated with GA 100 ppm for 72 hrs (Table 2).

\subsection{Physio-biochemical characteristics}

Table 3 reveals that seeds pretreated with $\mathrm{GA}_{3} 100 \mathrm{ppm}$ for 


\begin{tabular}{|c|c|c|c|c|c|}
\hline Treatments & OG & GP & MGT & SG & GE \\
\hline Control & 37.33 & $\begin{array}{c}22.22 \\
(28.10)\end{array}$ & 43.03 & 0.148 & 0.425 \\
\hline $\begin{array}{l}\text { Chilling }\left(50^{\circ} \mathrm{C}\right) \\
\text { for } 4 \text { weeks }\end{array}$ & 26.00 & $\begin{array}{c}23.33 \\
(28.84)\end{array}$ & 32.51 & 0.221 & 0.584 \\
\hline $\begin{array}{l}\mathrm{GA}_{3} 100 \mathrm{ppm} \text { for } \\
48 \mathrm{hrs}\end{array}$ & 19.00 & $\begin{array}{c}26.67 \\
(31.05)\end{array}$ & 25.63 & 0.284 & 0.756 \\
\hline $\begin{array}{l}\mathrm{GA}_{3} 100 \mathrm{ppm} \text { for } \\
72 \mathrm{hrs}\end{array}$ & 15.33 & $\begin{array}{c}41.11 \\
(39.86)\end{array}$ & 20.64 & 0.624 & 1.548 \\
\hline $\begin{array}{l}\mathrm{GA}_{3} 200 \mathrm{ppm} \text { for } \\
48 \mathrm{hrs}\end{array}$ & 16.33 & $\begin{array}{c}21.11 \\
(27.33)\end{array}$ & 23.77 & 0.204 & 0.665 \\
\hline $\begin{array}{l}\mathrm{GA}_{3} 200 \mathrm{ppm} \text { for } \\
72 \mathrm{hrs}\end{array}$ & 19.00 & $\begin{array}{l}25.56 \\
(30.34)\end{array}$ & 23.34 & 0.279 & 0.887 \\
\hline $\begin{array}{l}\mathrm{KNO}_{3} 250 \mathrm{ppm} \\
\text { for } 72 \mathrm{hrs}\end{array}$ & 19.00 & $\begin{array}{c}21.11 \\
(27.28)\end{array}$ & 29.97 & 0.174 & 0.586 \\
\hline $\begin{array}{l}\mathrm{KNO}_{3} 500 \mathrm{ppm} \\
\text { for } 48 \mathrm{hrs}\end{array}$ & 30.00 & $\begin{array}{c}35.55 \\
(36.57)\end{array}$ & 37.34 & 0.322 & 0.788 \\
\hline $\begin{array}{l}\text { Thiourea } 100 \\
\text { ppm for } 30 \text { mins }\end{array}$ & 30.00 & $\begin{array}{c}24.44 \\
(29.61)\end{array}$ & 37.67 & 0.158 & 0.472 \\
\hline $\begin{array}{l}\text { Thiourea } 200 \\
\text { ppm for } 30 \text { mins }\end{array}$ & 27.67 & $\begin{array}{c}31.11 \\
(33.88)\end{array}$ & 34.17 & 0.044 & 0.689 \\
\hline $\begin{array}{l}\text { PEG -6000 (-0.5 } \\
\text { MPa) for } 12 \text { hrs }\end{array}$ & 26.00 & $\begin{array}{c}33.33 \\
(35.25)\end{array}$ & 35.13 & 0.312 & 0.745 \\
\hline $\begin{array}{l}\text { PEG -6000 (-0.5 } \\
\text { MPa) for } 24 \mathrm{hrs}\end{array}$ & 32.67 & $\begin{array}{c}21.11 \\
(27.33)\end{array}$ & 41.31 & 0.196 & 0.382 \\
\hline $\begin{array}{l}\text { PEG -6000 (-1.1 } \\
\text { MPa) for } 12 \mathrm{hrs}\end{array}$ & 33.67 & $\begin{array}{c}27.78 \\
(31.79)\end{array}$ & 44.56 & 0.291 & 0.445 \\
\hline $\begin{array}{l}\text { PEG -6000 (-1.1 } \\
\text { MPa) for } 24 \mathrm{hrs}\end{array}$ & 36.00 & $\begin{array}{l}24.44 \\
(29.61)\end{array}$ & 43.06 & 0.143 & 0.434 \\
\hline SEm \pm & 0.821 & 0.825 & 1.508 & 0.016 & 0.128 \\
\hline $\operatorname{CD}(p=0.05)$ & 2.38 & 2.39 & 4.37 & 0.046 & 0.128 \\
\hline
\end{tabular}

OG: Onset of germination (days); GP: Germination percentage (\%); MGT: Mean germination time (days); Speed of germination; GE: Germination energy

72 hrs showed maximum imbibition capacity and mobilization efficiency of 2.23 and $73.33 \%$ respectively. This treatment also induced maximum $\alpha$-amylase $\left(9.47 \mathrm{mg}\right.$ starch degraded $\mathrm{min}^{-1}$ $\mathrm{g}^{-1}$ seed), protease $\left(544.01 \mu \mathrm{g}\right.$ amino acid released hour $\mathrm{r}^{-1} \mathrm{~g}^{-1}$ seed) and dehydrogenase activities $\left(6.30 \mathrm{mg} \mathrm{g}^{-1}\right.$ fresh weight of seed) along with higher total soluble sugars $\left(27.09 \mathrm{mg} \mathrm{g}^{-1}\right.$ fresh weight of seed) and lowest total phenols content (17.10 $\mu \mathrm{g} \mathrm{\textrm {g } ^ { - 1 }}$ fresh weight of seed) as compared to control (Table 4).Other treatments which resulted in higher germination were also effective in enhancing imbibition, activities of all three enzymes, mobilization of storage reserves and total
Table 2: Effect of seed invigoration treatments on seedling vigour in Angelica glauca

\begin{tabular}{|c|c|c|c|}
\hline Treatments & $\begin{array}{c}\text { Seedling } \\
\text { dry weight } \\
\text { (g) }\end{array}$ & $\begin{array}{l}\text { Seedling } \\
\text { vigor index I } \\
\text { (length) }\end{array}$ & $\begin{array}{l}\text { Seedling } \\
\text { vigor index } \\
\text { II (mass) }\end{array}$ \\
\hline Control & 0.008 & 69.06 & 0.179 \\
\hline $\begin{array}{l}\text { Chilling }\left(50^{\circ} \mathrm{C}\right) \\
\text { for } 4 \text { weeks }\end{array}$ & 0.011 & 113.02 & 0.246 \\
\hline $\begin{array}{l}\mathrm{GA}_{3} 100 \mathrm{ppm} \text { for } \\
48 \mathrm{hrs}\end{array}$ & 0.006 & 117.51 & 0.150 \\
\hline $\begin{array}{l}\mathrm{GA}_{3} 100 \mathrm{ppm} \text { for } \\
72 \mathrm{hrs}\end{array}$ & 0.007 & 181.35 & 0.282 \\
\hline $\begin{array}{l}\mathrm{GA}_{3} 200 \mathrm{ppm} \text { for } \\
48 \mathrm{hrs}\end{array}$ & 0.009 & 71.09 & 0.183 \\
\hline $\begin{array}{l}\mathrm{GA}_{3} 200 \mathrm{ppm} \text { for } \\
72 \mathrm{hrs}\end{array}$ & 0.009 & 117.56 & 0.222 \\
\hline $\begin{array}{l}\mathrm{KNO}_{3} 250 \mathrm{ppm} \\
\text { for } 72 \mathrm{hrs}\end{array}$ & 0.008 & 86.23 & 0.163 \\
\hline $\begin{array}{l}\mathrm{KNO}_{3} 500 \mathrm{ppm} \\
\text { for } 48 \mathrm{hrs}\end{array}$ & 0.008 & 156.10 & 0.270 \\
\hline $\begin{array}{l}\text { Thiourea } 100 \\
\text { ppm for } 30 \text { mins }\end{array}$ & 0.009 & 119.04 & 0.208 \\
\hline $\begin{array}{l}\text { Thiourea } 200 \\
\text { ppm for } 30 \text { mins }\end{array}$ & 0.008 & 138.11 & 0.244 \\
\hline $\begin{array}{l}\text { PEG -6000 (-0.5 } \\
\text { MPa) for } 12 \mathrm{hrs}\end{array}$ & 0.009 & 134.21 & 0.301 \\
\hline $\begin{array}{l}\text { PEG -6000 (-0.5 } \\
\text { MPa) for } 24 \mathrm{hrs}\end{array}$ & 0.011 & 77.11 & 0.231 \\
\hline $\begin{array}{l}\text { PEG -6000 (-1.1 } \\
\text { MPa) for } 12 \mathrm{hrs}\end{array}$ & 0.009 & 81.43 & 0.240 \\
\hline $\begin{array}{l}\text { PEG -6000 (-1.1 } \\
\text { MPa) for } 24 \mathrm{hrs}\end{array}$ & 0.009 & 100.59 & 0.232 \\
\hline SEm \pm & 0.0003 & 9.2444 & 0.0114 \\
\hline $\mathrm{CD}(p=0.05)$ & 0.001 & 26.78 & 0.033 \\
\hline
\end{tabular}

soluble sugars which are pre-requisites for germination.These beneficial treatments also showed decline in total phenol contents (Tables 3 and 4).

The significance of plant growth regulators, particularly gibberellins in breaking seed dormancy and enhancement of seed germination have been studied extensively and is well established (Bewley and Black, 1994; Thakur et. al., 2010). The beneficial effects of growth substances have been attributed in overcoming dormancy by causing changes in seed coat ultra structure (Solichatun et al., 2016), membrane repair, increased protein synthesis and more efficient mobilization of sugars and proteins (Srinivasan et al. 1999). In addition underlying key Physiological processes like mobilization of 
Table 3: Effect of seed invigoration treatments on mobilization efficiency and imbibition capacity in seeds of Angelica glauca

\begin{tabular}{|c|c|c|}
\hline Treatments & $\begin{array}{c}\text { Mobilization } \\
\text { efficiency } \\
(\%)\end{array}$ & $\begin{array}{c}\text { Imbibition } \\
\text { capacity } \\
(\%)\end{array}$ \\
\hline Control & 21.67 & 1.06 \\
\hline Chilling $\left(50^{\circ} \mathrm{C}\right)$ for 4 weeks & 26.33 & 1.10 \\
\hline $\mathrm{GA}_{3} 100 \mathrm{ppm}$ for $48 \mathrm{hrs}$ & 62.10 & 2.18 \\
\hline $\mathrm{GA}_{3} 100 \mathrm{ppm}$ for $72 \mathrm{hrs}$ & 73.33 & 2.23 \\
\hline $\mathrm{GA}_{3} 200 \mathrm{ppm}$ for $48 \mathrm{hrs}$ & 43.33 & 1.73 \\
\hline $\mathrm{GA}_{3} 200 \mathrm{ppm}$ for $72 \mathrm{hrs}$ & 56.44 & 1.57 \\
\hline $\mathrm{KNO}_{3} 250 \mathrm{ppm}$ for $72 \mathrm{hrs}$ & 39.10 & 1.13 \\
\hline $\mathrm{KNO}_{3} 500 \mathrm{ppm}$ for $48 \mathrm{hrs}$ & 54.67 & 1.89 \\
\hline Thiourea $100 \mathrm{ppm}$ for 30 mins & 28.34 & 1.26 \\
\hline Thiourea 200 ppm for 30 mins & 46.67 & 1.88 \\
\hline PEG $-6000(-0.5 \mathrm{MPa})$ for $12 \mathrm{hrs}$ & 48.00 & 1.41 \\
\hline PEG $-6000(-0.5 \mathrm{MPa})$ for $24 \mathrm{hrs}$ & 21.33 & 1.20 \\
\hline PEG -6000 (-1.1 MPa) for $12 \mathrm{hrs}$ & 45.33 & 1.63 \\
\hline PEG $-6000(-1.1 \mathrm{MPa})$ for $24 \mathrm{hrs}$ & 30.76 & 1.52 \\
\hline SEm \pm & 1.895 & 0.214 \\
\hline $\operatorname{CD}(p=0.05)$ & 5.49 & 0.62 \\
\hline
\end{tabular}

stored reserves, imbibitions capacity, lowered phenol content and other biochemical changes play a crucial role during seed germination(Yang et al., 2016; Tejavathi et al., 2017; Zhao et al., 2018). Improved germinability of seeds by invigoration is associated with a lower rate of lipid peroxidation and higher antioxidant enzyme activities (Bailly et al., 2000). Our results are in concurrence with above reports. Our studies have revealed that $\mathrm{GA}_{3} 100$ ppm for $72 \mathrm{hrs}$ was the most effective combination of concentration and duration for inducing germination and seedling vigour. Grappin et al. (2000); Kaur et al. (2000) have also reported that gibberellins are known to stimulate germination, since they obviate the requirement of seeds for various environmental cues, promote germination and counteract the inhibitory effects of ABA. Evidences have been cited on the role of gibberellins and cytokinins in triggering enzyme activity leading to germination.Better germination and seedling vigour characteristics in $A$. glauca seeds invigorated with $\mathrm{KNO}_{3} 500 \mathrm{ppm}$ may be attributed to the potassium ions which improve water relations which can affect water potential of seeds and help in imbibition. Our results showed substantial improvement in germination characteristics and vigour by osmoconditioning with PEG 6000 at $-0.5 \mathrm{MPa}$ for $12 \mathrm{hrs}, \mathrm{KNO}_{3} 500 \mathrm{ppm}$ for $48 \mathrm{hrs}$ and thiourea 200 ppm for 30 mins which can improve water relations in seeds.

All beneficial treatments resulted in early onset of germination which might be due to early induction of protein $\alpha$-amylase.

Table 4: Effect of seed invigoration treatments on enzyme activities, total soluble sugars and total phenol contents in seeds of Angelica glauca

\begin{tabular}{|c|c|c|c|c|c|}
\hline Treatments & $\begin{array}{l}\alpha \text {-amylase (mg } \\
\text { starch degraded } \\
\min ^{-1} \mathrm{~g}^{-1} \text { ) }\end{array}$ & $\begin{array}{c}\text { Protease ( } \mu \mathrm{g} \text { ami- } \\
\text { no acid released } \\
\text { hour }^{-1} \mathrm{~g}^{-1} \text { ) }\end{array}$ & $\begin{array}{l}\text { Dehydroge- } \\
\text { nase (mg g-1 } \\
\text { fresh weight) }\end{array}$ & $\begin{array}{l}\text { Total soluble } \\
\text { sugars (mg g } \\
\text { fresh weight) }\end{array}$ & $\begin{array}{l}\text { Phenols ( } \mu \mathrm{g} \mathrm{g}^{-1} \\
\text { fresh weight) }\end{array}$ \\
\hline Control & 3.14 & 345.02 & 4.40 & 12.00 & 25.08 \\
\hline Chilling $\left(50^{\circ} \mathrm{C}\right)$ for 4 weeks & 3.42 & 467.18 & 4.50 & 13.00 & 24.99 \\
\hline $\mathrm{GA}_{3} 100 \mathrm{ppm}$ for $48 \mathrm{hrs}$ & 3.09 & 464.32 & 4.90 & 23.00 & 20.00 \\
\hline $\mathrm{GA}_{3} 100 \mathrm{ppm}$ for $72 \mathrm{hrs}$ & 9.47 & 544.01 & 6.30 & 27.09 & 17.10 \\
\hline $\mathrm{GA}_{3} 200 \mathrm{ppm}$ for $48 \mathrm{hrs}$ & 8.59 & 463.27 & 4.40 & 25.00 & 26.01 \\
\hline $\mathrm{GA}_{3} 200 \mathrm{ppm}$ for $72 \mathrm{hrs}$ & 3.69 & 471.00 & 4.60 & 22.99 & 25.00 \\
\hline $\mathrm{KNO}_{3} 250 \mathrm{ppm}$ for $72 \mathrm{hrs}$ & 3.50 & 464.32 & 4.40 & 22.00 & 28.09 \\
\hline $\mathrm{KNO}_{3} 500 \mathrm{ppm}$ for $48 \mathrm{hrs}$ & 3.61 & 465.75 & 6.00 & 25.90 & 20.00 \\
\hline Thiourea 100 ppm for 30 mins & 3.52 & 415.64 & 4.60 & 20.00 & 25.99 \\
\hline Thiourea 200 ppm for 30 mins & 3.31 & 475.77 & 5.40 & 22.01 & 20.90 \\
\hline PEG -6000 (-0.5 MPa) for $12 \mathrm{hrs}$ & 3.63 & 470.98 & 5.70 & 22.08 & 22.00 \\
\hline PEG -6000 (-0.5 MPa) for $24 \mathrm{hrs}$ & 3.46 & 455.25 & 4.30 & 23.06 & 24.00 \\
\hline PEG -6000 (-1.1 MPa) for $12 \mathrm{hrs}$ & 3.50 & 468.61 & 4.80 & 22.01 & 19.99 \\
\hline PEG -6000 (-1.1 MPa) for $24 \mathrm{hrs}$ & 3.42 & 469.09 & 4.60 & 23.00 & 26.00 \\
\hline SEm \pm & 0.0003 & 0.0217 & 0.0204 & 0.0014 & 0.0003 \\
\hline $\operatorname{CD}(p=0.05)$ & 0.001 & 0.063 & 0.059 & 0.004 & 0.001 \\
\hline
\end{tabular}


Since, in seeds $\alpha$-amylase is the enzyme which is most frequently credited with the initial attack on starch granules, resulting in the formation of simple sugars and ATP which is required for seed germination process. Reports of Trethewey and Smith (2000) were also in concurrence with our studies. The role of aleurone layer in forming the mRNA for protein $(\alpha$-amylase) synthesis has been reported by Bewley and Black (1994). Similar findings have been made by Appleford and Lenton (1997) who reported that gibberellins are known to promote the formation of amylases, proteases and dehydrogenases which degrade the reserve materials in seeds. Seed germination is a complex process initiating with the absorption of water and after a pause leading to activation of enzymes.The enhanced activity of $\alpha$-amylase during the pre-sowing treatments may be attributed to the higher imbibition capacity during the above treatments, activation of hydrolases resulting in increased breakdown of starch into soluble sugars which supports seed germination and vigourous seedling growth. This is in concurrence to our findings which showed higher imbibition capacity during the above treatments resulting in increased contents of total soluble sugars.

\section{Conclusion}

The findings suggest that presowing seed treatments like $\mathrm{GA}_{3}$ $100 \mathrm{ppm}$ for $72 \mathrm{hrs}, \mathrm{KNO}_{3} 500 \mathrm{ppm}$ for $48 \mathrm{hrs}$, PEG 6000 at $-0.5 \mathrm{MPa}$ for $12 \mathrm{hrs}$ and thiourea $200 \mathrm{ppm}$ for 30 mins are of great significance to pave the way for conservation through improving seed germination and vigour.

\section{References}

Appleford, N.E.J., Lenton, J.R., 1997. Hormonal regulation of $\alpha$-amylase gene expression in germinating wheat grains. Physiologiae Plantarum 100, 534-542.

Bailly, C., Benamar, A., Corbineau, F., Come, D., 2000. Antioxidant systems in sunflower (Helianthus annus L.) seeds as affected by priming. Seed Science Research 10, 35-42.

Bewley, J.D., Black, M., 1994. Seed: Physiology of development and germination. Trakia Journal of Sciences 1, 201-223.

Bhardwaj, A.K., Kapoor, S., Naryal, A, Bhardwaj, P., Rambhau A.W., Kumar, B., Chaurasia, O.P., 2016. Effect of various dormancy breaking treatments on seed germination, seedling growth and seed vigour of medicinal plants. Tropical Plant Research 3, 508-516.

Bialecka, B., Kepczynski, J., 2010. Germination, $\alpha$-, $\beta$-amylase and total dehydrogenase activities of Amaranthus caudatus seeds under water stress in the presence of ethephon or $\mathrm{GA}_{3}$. Series Botanica 52, 7-12.

Butola, J.S., Badola, H.K., 2004. Effect of pre-sowing treatment on seed germination and seedling vigour in Angelica glauca, a threatened medicinal herb. Current Science 87, 796-799.

Dey, P.M., 1990. Methods in plant biochemistry. Vol.-II.
Carbohydrates (Publ.) Acad. Press London.

Filner, P., Varner, J.E., 1967. A test for de novo synthesis of enzyme. Density labeling with water of barley, $\alpha$-amylase induced by gibberellic acid. Proceedings of The National Academy of Sciences 58, 1520-1526.

Grappin, P., Bouinot, D., Sotta, B., Maginiac, E., Jullien, M., 2000. Control of seed dormancy in Nicotiana plumbaginifolia: post-imbibition abscisic acid synthesis imposes dormancy maintenance. Planta Journal, 210, 279-285.

International Seed Testing Association (ISTA). 1976. International Rules for Seed Testing. Proceedings International Seed Testing Association 31, 1-52.

Kandari, L.S., Rao, K.S., Maikhuri, R.K., Chauhan, K., 2008. Effect of pre-sowing temperature and light on the seed germination of Arnebia benthamii: An endangered medicinal plant of Central Himalaya, India. Journal of Medicinal Plants Research 2, 5-11.

Kaur, S., Gupta, A.K., Kaur, N., 2000. Effect of $\mathrm{GA}_{3}$, kinetin and indole acetic acid on carbohydrate metabolism iLee, $\mathrm{S}$. S., \& Kim, J.H., 2000. Total sugars, $\alpha$-amylase activity, and emergence after priming of normal and aged rice seeds. Korean Journal of Crop Science 45, 108-111.

Maguire, J. D., 1962. Speed of germination-aid in selection and evaluation for emergence and vigour. Crop Science 2, 176-177.

McDonald, C.E., Chen, L.L., 1965. Lowry modification of the Folin reagent for determination of protease activity. Annals of Clinical Biochemistry 10, 175.

Nautiyal, M.C., Prakash, V., Nautiyal, B.P., 2002. Cultivation techniques of some high altitude medicinal herbs. Annals of Forestry 10, 62-67.

Negi, P., Nautiyal, B.P., Thakur, N., Negi, M., Kumari, V., Meena., 2017. Effect of different pre-sowing treatments on seed germination of walnut (juglans regia L.). Global Journal of Bioscience and Biotechnology. 6, 497-499.

Rouhi, H.R., Rahmati, H., Saman, M., Shahbodaghloo, A.R., Karimi, F.A., Moosavi, S.A., Rezaei, M.E., Karimi, F., 2012. The effects of different treatments on dormancy breaking of Ferula gummosa Boiss. International journal of Agricultural Science 2, 598-604.

Sastry, A.R.K., Chatterjee, S., 2000. Prioritization of medicinal plants of India. In: Setting biodiversity conservation priorities for India. Journal of Tropical Medicinal Plants 2, 467-473.

Singleton, V.L., Orthofer, R., Lamuela-raventos, R.M., 1999. Analysis of total phenols and other oxidation substrates and antioxidants by means of Folin-Ciocalteu reagent. Methods in Enzymol 299, 152-178

Solichatun, S., Kumala., D., Rarastoeti, P., 2016. The effects of physical and hormonal treatments on dormancy breaking and the changes in seed coat ultrastructure of Delonix regia . Nusantara Bioscience 8, 94-102.

Srinivasan, A.K., Saxena, S., Singh, B.B., 1999. Osmo and 
hydropriming of mustard seeds to improve vigour and some biochemical activities. Seed Science and Technology 27, 785-793.

Srivastava, A. K., Sareen, K., 1974. Physiology and biochemistry of deterioration of soybean seeds during storage. Plant Horticulture 7, 545-547.

Tejavathi, D.H., Raveesha, H.R., Nijagunaiah, R., Lakshmana, A.C., Madhusudhan, R. V., Jayashree, D.R., 2017. Estimation of primary metabolites and phenols in the seeds of five species of Calamus and their role on germination. International Journal of Pure and Applied Biosciences 5, 777-783.

Thakur, A., 2008. Overcoming the germination problems in certain endangered medicinal species of Indian Western Himalayas. Acta Horticulture 786, 219-228.

Thakur, A., Thakur, P.S., Dutt, V., Thakur, C.L., 2010. Conservation of Podophyullum hexandrum- an endangered medicinal herb through seeds. Indian Journal of Plant Physiology
15, 110-116.

Thakur, A., Himangini, 2015. Revival of germination and vigour of aged seeds of Withania somnifera by seed invigoration treatments . Indian J Plant Physiology 20 391-395.

Trethewey, R.N., Smith, A.M., 2000. Starch metabolism in leaves. In: Leegood, R.C., Sharkey T.D. (Ed.), photosynthesis: physiology and metabolism. Kluwer academic publishers, Dordrecht, the Netherlands, 205-231.

Yang, R., Wang, P., Elbaloula, M.F., Gu, Z., 2016. Effect of germination on main physiology and biochemistry metabolism of Sorghum seeds. Bioscience Journal 32, 378-383.

Zhao, M., Zhang, H., Yan H., Qiu,L., Baskin C.C., 2018. Mobilization and role of starch, protein and fat reserves during seed germination of six wild grassland species. Frontiers in Plant Science. Published 27 Feb,doi:10.3389/ fpls.2018.00234. 